passing from experiences of sentiment to those of stark tragedy. A pleasure-loving, impressionable, though talented young admirer from the east, with open atheistic avowals, pays ardent court, but quickly finds the conflicting cultural and religious backgrounds a decided impediment. The young French woman's deeply cherished religious ideals and loyalty to church standards causes a breaking of their friendly association, and both are married to others. Later occured the tragic deaths of the young woman's husband and likewise of her former admirer's wife, from widely removed causes. Following the youth's return to Dubuque from service in the Mexican war, after months of hospitalization in recovery from serious wounds suffered at Chapultepec, and his ultimate conversion and acceptance of the rites of the church, they were happily reunited in association and were married.

The scenes are largely laid in old Dubuque and along the Mississippi, utilizing as a background events developing from the influx of settlers from New England and the old South, coming into the sparsely settled but growing communities of Iowa, with their conflicting racial traits and standards, groups such as made up the border life of every new state. Dr. Hoffman again demonstrates his ability as an author and cleverness as a historian, as well as skill in using a novel in disclosing the discipline of the church, as evidenced by its adherents in this tale when controversial aspects are debated.

\title{
INDIANS CLAIM MILLIONS YET DUE
}

The proud boast of a century and longer that not an acre of Iowa land was taken from the Indians owning it without payment therefor, is now challenged. Whatever may have been the course pursued in other states, the government of the United States made treaties with the Indian tribes, purchasing the Iowa lands outright and opened them for settlement. 
That much is not disputed. But, now comes the claim that the government officials pursued the course of awaiting payments from settlers, in some cases, before making final settlement with the tribes. Then, this delay in turn was visited upon the Indians, without final settlement, and now at long last turns up a claim for settlement.

Particularly are involved the consolidated Otoe and Missouri Indian tribes, now numbering only a "few hundred people," whose representatives have filed a claim in suit at Washington for $\$ 9,726,921$ with interest under treaties dating back to 1830 . The acres involved represent practically the three western tiers of Iowa counties from the Missouri to the Minnesota border, and other such area in Minnesota, Nebraska, Kansas and Missouri. The claim of the tribal attorneys is weakened somewhat by statement in their petition that the lands had a certain actual value, upon which they rely, rather than upon actual amounts defaulted in payment of money, goods and services agreed to be paid therefor.

A question of fact seems to be the crux of the situation -with bookkeeping and accounting having much to do with the consideration and delivery of same as provided in the treaty. How carefully and accurately the records of the tribe and the government have been kept and preserved must now develop.

\section{PEIJLA CHRISTIAN CENTENNIAL}

A noteworthy centennial observance took place on August 20, in the West park at Pella, commemorating the arrival there of 800 Hollanders in 1847. The band of settlers came to America and founded the original colony at Pella, under the leadership of Dominie Hendrick Peter Scholte, grandfather of Dr. John Nollen, of Grinnell, and Gerard Nollen, of Des Moines.

The celebration program of the day was in keeping with the religious history and experiences which resulted in the emigration to America, and was participated in by speakers from various Pella churches. An offering 
Copyright of Annals of Iowa is the property of State of Iowa, by \& through the State Historical Society of Iowa and its content may not be copied or emailed to multiple sites or posted to a listserv without the copyright holder's express written permission. However, users may print, download, or email articles for individual use. 